\title{
Communication of Da'wah Nahdlatul Ulama Dawah Institution (LDNU) in Preventing Hoax News
}

\author{
Mustafirin $^{1 *}$ \& Hatta Abdul Malik ${ }^{2}$ \\ ${ }^{1}$ Sekolah Tinggi Agama Islam Walisembilan, Semarang, Indonesia \\ 2UIN Walisongo, Semarang, Indonesia \\ *mustaghfirin.mag@gmail.com
}

\begin{abstract}
This study aims to find out how the efforts made by LDNU in building public perception to prevent hoax news through the mass media. The research was conducted with a da'wah communication approach to build awareness of the phenomenon of hoax news. The research was conducted through a qualitative approach through a meta-analysis of the literature. Meta-analysis is a unique technique used to create an integrative or methodology review. First, LDNU creates social media accounts for news education and control; second, $L D N U$ cooperates with the media and other institutions to narrow the space for slander and hoaxes; third, LDNU continues to use the basis of the ITE Law as a guide in the use of social media. Eight management principles are applied as an integral part in building awareness, perception, knowledge, skills, and social responsibility in preventing the spread of hoax news and other harmful content.
\end{abstract}

Keywords: da'wah communication; social media; hoax; LDNU.

\begin{abstract}
ABSTRAK
Penelitian ini bertujuan untuk mengetahui baaimana upaya yang dilakukan oleh LDNU dalam membangun persepsi masyarakat untuk mencegah berita hoaks melalui media massa. Penelitian dilakukan dengan pendekatan komunikasi dakwah sebagai upaya membangun kesadaran terhadap fenomena berita boaks. Penelitian dilakukan melalui pendekatan kualitatif melalui meta analisis literature. Meta analisis adalah teknik khusus yang digunakan untuk membuat tinjauan integratif atau tinjauan metodologi. pertama, LDNU membuat akun media sosial dalam edukasi dan kontrol berita; kedua, LDNU bekerjasama dengan media dan lembaga lainnya untuk mempersempit ruang gerak fitnah dan hoaks; dan ketiga, LDNU tetap menggunakan dasar Undang-Undang ITE sebagai pedoman dalam penggunaan media sosial. Diterapkan delapan prinsip pengelolaan sebagai bagian integral dalam membangun kesadaran, persepsi, pengetahuan, keterampilan, dan tanggung jawab sosial dalam mencegah penyebaran berita boaks dan konten-konten negatif lainnya.
\end{abstract}

Kata Kunci: komunikasi dakwah; media sosial; hoaks; IDNU.

Received: Oktober 2021. Accepted: November 2021. Published: Desember 2021. 


\section{INTRODUCTION}

Communication is a basic need in human life. This relates to human efforts in building interactions and relationships with each other. In the era of digital industrialization, the interaction takes place face-to-face and utilizes the media. Information technology offers a new way of interacting with each other, which was initially intertwined in the real world and turned to the virtual world (Juditha, 2018: 32). This relates to the interaction process and its influence on the dimensions of human life (Juliswara, 2017: 143).

Communication in the digital space takes place freely regardless of social background. The professions of teachers, pedicab drivers, subdistrict employees, and entrepreneurs reinforce each other's information according to their respective experiences. This encourages perceptions to establish a positive communication process and prevent fake news (Silalahi, 2017: 135). Manipulation of news content that is false hate speech and can cause conflict uses many digital media channels. This can lead people to hate each other.

The communication perspective views that connectedness exists between humans so that in the process, humans need effective, fluent communication and contain positive information. This aims to avoid conflict and division (Ridwan, 2016: 17). Communication plays a significant role in anticipating the spread of manipulative and provocative news. This relates to preventive efforts against the dissemination of hoax news, hate speech, and others.

The results of research from Mastel (2017) explain that the channels used to spread hoax news include $34.90 \%$ of websites, chat applications (such as Whatsapp, Line, telegram) by $62.80 \%$, and social media (such as Instagram, Twitter, path) which reached $92.40 \%$. In 2016, the Ministry of Communication and Informatics recorded as many as 800 thousand sites in Indonesia indicated as the leading distributors of fake news (Juditha, 2018: 44).

Research conducted by Manalu S Rouli, Pradekso Tandiyo, and Setyabudi Djoko (2018) on Understanding the Tendency of Media Users to Consume Fake News was conducted to observe the spread of hoax information in Indonesia. The distribution is carried out through audience profiling, namely consuming and distributing fake news based on media usage patterns, mapping the characteristics of fake news and tracing sources in spreading hoaxes, and understanding audience behavior in 
consumption through the media. This research method uses a survey with Semarang city residents who are recorded as active internet users.

The study results indicate that the consumption pattern of media users who are in the age range of 15-30 years is considered to have a high risk of exposure to hoaxes. This also allows him to be the perpetrator of the spread of hoax information. The age group of 15-20 is considered to have a high tendency to believe in hoax information. This research has implications for the importance of strengthening digital literacy for active internet users.

Henri Septanto's research (2018) on the influence of hoaxes and hate speech in cybercrime with simple technology in people's social lives. This study explores the potential for social disharmony caused by the spread of hoax news in the community. The results show that hoaxes are information poisons that harm internet users. The public is expected to be more selective in selecting and sorting information. Institutionally, the active role of KOMINFO and POLRI, especially the Cyber Crime Division, is significant in anticipating the dangers of hoaxes.

Another study was conducted by Hana Noor Divine (2018) on Women and Hoax News Processing on WhatsApp. The purpose of this study was to investigate how women process hoax messages about child abduction on WhatsApp. The study results concluded that women could think critically, but messages about child abduction tend to be biased by emotions. Therefore, when there is a message about child abduction, women will immediately send it to others. Second, increasing women's media literacy is seen as being able to help stop the circulation of hoaxes on WhatsApp about child abductions. Third, the attitude change caused by the hoax message about child abduction follows the peripheral temporal processing line and is unpredictable. Researchers categorize this uncertainty as reactive behavior.

Based on the research results conducted by APJII (2019-2020), it is stated that the potential for spreading hoax news is mainly related to political, health, and religious information. These three things are seen as messages of manipulation and provocation widely disseminated in the public sphere. With the high intensity of fake news, many people think that honesty and clarity of thought have been lost. Mutual suspicion and the emergence of public distrust (Ali, 2017: 90).

The communication perspective views that the mechanism for the emergence of interactions between people is interwoven through symbols 
and information tools that can be stored in the dimensions of space and time (Ali, 2017: 94). This shows the process of disseminating information as a circulation condition that takes place continuously. In Indonesia, the spread of hoax news occurs when the momentum of democratic contestation is approaching, such as the General Election, Presidential Election, and Regional Head Election. This is related to the political campaign process, which brings down each other between contestantseven using sensitive issues such as religious and racial issues. This, of course, has a significant impact on the reality of the harmony of social life (Sukmana, 2013: 40).

In the name of freedom, the internet, and social media users often feel they have full rights to their accounts. Netizens feel it is okay to upload any text, image, or video to their account. Although sometimes, they are not aware that what they upload can violate the ethics of communicating in social media (Siswoko, 2017: 17). The uproar that occurs on social media is considered to spread to the real world if it is not immediately addressed. The conversations contained in social media can construct public understanding in addressing specific issues and influencing people's lives. The internet has become a space for packaging social reality, which is carried out through symbolic engineering that links specific texts, images, and symbols (Fakhruroji, Rustandi \& Busro, 2020).

Hoax is the effect of online and offline social openness, which becomes a social threat. In the context of the state, the President of Indonesia, Jojo Widodo, through the Coordinating Minister for Political, Legal, and Security Affairs, requested that the spread of hoax news be immediately stopped because it could cause slander to divide the nation. Wiranto, as the Coordinating Minister for Political, Legal, and Security Affairs, said that:

"People will feel aggrieved by this fake news. People will be confused about which news is true or false. This point of weakness becomes an opportunity for individuals to take advantage of the situation so that a sense of hatred can be easily digested at the time of the situation. Of course, division, damage, noise, and community comfort will be disturbed" (Tarigan, 2017).

The untruth of information spread on social media often creates identity sentiments that lead to blasphemy and hate speech (Juliswara, 2017: 142-143). In responding to this problem, all elements of society are expected to formulate appropriate concepts in anticipating the occurrence 
of chaos on social media. On the other hand, the issue of overcoming the chaos on social media through law enforcement does not need to undermine the spirit of freedom of expression in a democratic system. Hoax resistance is built on the principle of togetherness and structure so that the elements of democracy are maintained without any disputes.

Counter hoax narratives can be done through various approaches. One of them is through a religious communication approach that displays diversity. Thus, social and religious communication will strengthen efforts to prevent the spread of hoax news. In this case, digital literacy must also be strengthened with the concept of da'wah, which leads to the formation of awareness and a productive and positive social ecosystem. Efforts to strengthen da'wah institutions as an alternative to building a campaign against hoax narratives must be carried out in strengthening social cohesiveness (Ridwan, Dulwahab, Rustandi, \& Fatoni, 2021).

The communication role of religious institutions in making people aware and providing critical skills in anticipating hoaxes must be carried out intensively and continuously. One of them is building a more intelligent and socially ethical society when using social media. Da'wah communication requires interaction between da'i as communicators and Madhu as communicants. Da'wah communication is oriented towards the purpose of da'wah in forming a person following the values of Islamic teachings (Rohman, 2019).

Da'wah communication seeks to answer social anxiety from any impact of using mass media as a means of social communication. In this case, the growing use of internet media as a means of mass communication raises three social problems related to the loss of cultural identity, the vulnerability of spirituality, and the lack of social control (Muhtadi, 2012). Phenomena like this occur during people's lives due to the vital flow of information, which is sometimes uncontrollable and creates a social shock. Therefore, the existence of da'wah institutions that carry out da'wah communication in building counter-narrative discordant and misleading information is seen as strengthening efforts to strengthen media, information, and digital literacy for the community (Rustandi \& Muchtar, 2020).

One of the da'wah institutions seen as having a significant role in social control efforts and strengthening the spiritual side of society is the Nahdlatul Ulama Da'wah Institution (LDNU). This institution is not only positioned as an institution that manages conventional da'wah activities, 
including the management of da'wah activities related to the use of digital technology. LDNU is seen as a da'wah institution that actively counters narration of hoax messages from an Islamic perspective. The da'wah communication efforts are carried out by planting awareness, strengthening networks, and providing critical skills to the subject and object of da'wah in countering manipulative and provocative information.

This study aims to analyze the efforts made by the Nahdlatul Ulama Da'wah Institute (LDNU) in countering hoax narratives. This is viewed from managing da'wah activities that are oriented towards strengthening the spiritual side based on the values of Islamic teachings. In addition, it is also carried out by analyzing LDNU's social control efforts in anticipating the impact of spreading hoax information in the community. So it is hoped that there will be a model of institutional da'wah communication that carries out preventive efforts in the dissemination of hoax information.

This study uses a qualitative approach that aims to explore the phenomenon of hoaxes in-depth. This qualitative research contains a literature review and theoretical concepts related to the research problem, which relates to the spread of hoaxes and social media to build public perception. Furthermore, the research was conducted by observation and discourse analysis. The literature review was carried out through a literature meta-analysis technique, a unique technique used to make an integrative or methodological review. Meta-analysis is carried out through several research steps, namely: (1) Looking for potential written works that can be used as references for this research; (2) Processing the criteria of the findings so that they are relevant to the problem; and (3) Conclude from the data that has been processed.

Data collection techniques were also carried out through observation and discourse analysis. That is to see and examine the movement of the NU da'wah institution in providing understanding to the public about hoax news. This is based on the assumption that news content will strongly influence people's lives. The research steps were carried out through several stages. They started by identifying relevant articles to support literature related to communication and hoaxes. Of course, prioritized articles published in 2000 - 2020. Furthermore, from sources that have been received, they will be further examined to maintain relevance in this discussion. The references used are articles, journals, and books containing hoaxes issues.

It is next, classifying articles and collecting data. From the articles 
that have been collected, the author looks for articles that match the keywords. This is done to compile data and answer research problems. Then make observations to see the effect of hoax news and how intensive the movement of the NU da'wah institution is in anticipating hoax news. Lastly, conduct a discourse analysis to explore LDNU's efforts in building public perceptions regarding preventing the spread of hoax news.

\section{RESULTS AND DISCUSSION}

\section{Anti Hoax Da'wah Communication}

Harold Laswell (1960) defines communication by describing communication through the questions (1) who says, (2) what (3) and with channel (4) to whom (5) with what effect; who says, with what channel, to whom, with what influence (Mulyana, 2010: 68-69). Not only is the sender of the message and who is the recipient of the message, but the impact of the message itself has a strong influence on changing the audience's situation.

The application of communication is a fundamental process of every activity both in the individual, communal and social spheres. Practically, communication is necessary for everyone to develop themselves, build relationships with others, and present ideas through various media channels. The communication perspective views interaction as an event of transmission and transaction of ideas, experiences, and feelings. In this case, communication is exchanging messages through certain symbols and oriented towards transformations in thoughts, feelings, and actions (Rustandi, 2020).

The da'wah perspective views communication as a way of building interaction to achieve da'wah's goals. The purpose of da'wah is to form a personality under the values of Islamic teachings. Da'wah activity is seen as social interaction within amar maruf nahi munkar. Da'wah activities are built through a communication process that requires a change in attitudes and situations towards a better direction (Rohman, 2019). Da'wah communication activities are carried out to build awareness and understanding in internalizing and actualizing the values of Islamic teachings to achieve happiness in the world and the hereafter (Rustandi \& Hanifah, 2019).

Various communication channels were developed to circulate information in the community. Information channels are developed with 
advanced technology to have a broad and fast deployment range. Critically, the cultivation of communication media views that the faster and more intensive the reach of information in a communication process, the easier the process of instilling trust in the public. In other words, the speed of information flow affects the conditions and situations of the audience.

Social media is an important communication channel in the context of digital life. Where social media users reach a significant number. In Indonesia, every year, internet and social media users are increasing. It is noted that internet users in Indonesia have reached 202 million people, with active social media users reaching 180 million people. This figure shows the trend of using social media as a communication channel used with various community interests at the personal, interpersonal and communal levels (Rustandi, \& Muchtar, 2020; Fakhruroji, Rustandi \& Busro, 2020).

Howard and Parks explain the division of social media into three types: production of tools, information facilities, and planning of media content in the form of personal messages, news, ideas, and cultural products that make up digital. The management of communication messages is carried out personally, organizationally, and industrially. So that social media can eliminate the limitations of space and time, both geographically and territorially. The acceleration of the distribution of the flow of information is getting faster to the community, so it requires skills in receiving, processing, designing, and re-disseminating messages critically and selectively (Alif, 2018: 417).

Social skills must accompany using social media to distribute news and information openly. In this case, the recipient of the news must understand interpreting the content of the news. Hoax is a phenomenon that must be taken seriously and become a common concern. Efforts to prevent hoax news must continue to be carried out in various spheres of community life. Both the government and the public should anticipate the spread of fake news (hoax).

Moreover, this dissemination is mainly done through social media channels such as Facebook and WhatsApp. From a psychological perspective, the dissemination of hoax information affects the user's emotional state, especially alluding to negative emotions, such as anger, fear, disappointment, and sadness. Dominant emotions tend to encourage people to respond quickly without thinking. So, not a few cases of social violence started from social media.

The da'wah perspective views that communication channels must be 
based on the constancy of values and attitudes related to social ethics. In this case, da'wah is oriented to the formation of human morality under the moral values of karimah (Rustandi, 2019). Therefore, Islam regulates the joints of human behavior in social interactions. Ethics is a form of guidance for human behavior based on the size of the human mind, while morals are taken from the Latin "mores" plural of "mos" which means custom (Ya'qub, 1998: 14). Both ethics, morals, and morals are oriented towards efforts to improve the human person. All three are used as a code of conduct that regulates human social interaction, including social media as a channel of public communication.

Social media is used for various purposes. Both are related to economic, educational, social, cultural, political, and religious aspects. Based on data from Hootsuite (2021), access to social media is mainly done via mobile phones, where most social media users access various features provided by their gadgets. So that all users can participate in building social networks online, whether the content of messages is in the form of blogs, group forums, or online communities. In another position, social media has significant potential as a channel for spreading hoax news. This is reinforced by a survey conducted by the Ministry of Communication and Informatics (2020), which notes that the digital literacy index of the Indonesian people is still moderate at 3.47. The highlighted aspect is the trend of spreading hoax news that is spread through social media, where almost 70 percent of social media users can become victims and even perpetrators of spreading hoax news.

Buente and Robbin conducted an investigative study on the channel of information through the internet to Americans between March 2000 and November 2004. The results showed that there are four dimensions of internet use, namely information (information utility), pleasure (leisure/fun activities), communication (communication) and transactions (Buente, 2008: 79). In other words, the use of the internet as a communication channel boils down to the four dimensions above, both as a channel of information, pleasure, communication, and transactions. The spread of fake news is related to the ethics of using the internet. The growing phenomenon is related to the misuse of the internet, which is placed as a space for freedom of speech. This freedom of speech comes from a country with a liberal system that states that every individual in the group can give an opinion, corner other individuals, and praise someone without certain limitations (Floridi, 2010: 56). 
This is misused when freedom of speech is used for information dissemination without any social responsibility. So that in the end, the spread of news or information is not controlled and tends to lead to the disintegration of the nation. Freedom of speech is widely misused to make information with the nuances of a hoax. Sometimes it is intentionally created to create a sensation on social media with specific interests. The results of other studies also show the behavior of social media users when receiving hoax news. According to a psychological view, two factors easily cause users to believe hoax information: the suitability of information with his opinions and behavior (Respati, 2017: 2017). In other words, hoax information received and disseminated shows the characteristics of a person-psychological tendency to judge that someone receives hoax information and even redistributes it if it suits him.

The results also support the opinion of David Harley (2008: 34), who identifies hoaxes in general. In his view, the characteristics of hoax information are as follows: first, hoax information usually has the characteristics of a chain letter by including sentences such as "Spread this to everyone you know. Otherwise something unpleasant will happen". Second, hoax information usually does not include the date of the incident or does not have accurate or verifiable data, such as "yesterday" or "issued by." statements that do not provide clarity. Third, hoax information usually does not have an expiration date on information alerts, even though they exist nor will it prove anything, but it can have a lasting effect on anxiety. Fourth, no identifiable organization is cited as the source of information or includes the organization but is not usually associated with the information.

Positive feelings will arise if his opinion or belief gets recognition from his environment. So that someone tends to ignore the information he receives is true or false. They will redistribute the information without any filter. This condition is exacerbated if the disseminator of hoax information does not know the use of internet technology. In addition, unlimited use of the internet is seen as having the potential to receive information overload. In this case, a person's intensity in using the internet needs to be controlled so that it is not easy to receive information. This is because the phenomenon of 'information flooding' fills the digital communication space that spreads to every user.

We Are Social (2021) notes that the average internet user in Indonesia spends about 8 to 9 hours in one day, with an average use of social media of around 3 hours 14 minutes (Fakhruroji, Rustandi \& Busro, 
2020). This position allows each user to quickly receive information without going through a filter, selection, and critical process in process. On the other hand, there are symptoms of social media users responding to information by providing comments to be perceived as understanding and understanding. That is, the user wants to be considered skilled by other users. This is an opportunity for the spread of hoaxes because they want to be considered skilled or knowledgeable without carrying out a verification process on the information they receive. Perpetrators of hoax news spreaders use this social network to viral information with certain tendencies and interests (Utami, 2018: 63).

The behavior of spreading hoaxes through social media is strongly influenced by newsmakers, both individually and in groups, from those with low to high education. The spread of hoax news is structured and massively carried out. This relates to the user's technological skills in utilizing digital technology facilities. The tendency of applicative skills in the use of search engines has the potential to filter information. Lazonder (2000) shows a difference between someone who has particular expertise in using search engines and people who are new or unfamiliar with using search engines. Users who have more experience using search engines will tend to be more systematic in conducting searches than those who have minimal experience (novice) (Lazonder, 2000: 2-7). In this case, the user's technological skills apply to determine how to access, design and disseminate information.

Hoax information is often disseminated and sourced from fake news and made in a social network to protect personal and group interests. Often social media users consciously spread lies to aid the planned agenda. Hoax spreaders can be from personal circles, communities, corporations, state institutions, and the military. Hoax spreaders often make false propaganda so that their interests can be protected. Hoax information is made so that the general public no longer focuses on the real problem and will be trapped in bombastic things that are not the main problem (Bosma, 2017: 6). The position of the disseminator of hoax information that is considered credible makes users feel confident that the information is accurate and disseminated without being rechecked.

The Islamic perspective views that messages or information must bring goodness to both the perpetrator and the recipient. In this case, the disseminator is a da'i or communicator who spreads goodness to the Madhu or communicant. Islam regulates communication ethics, where 
communication within the framework of social interaction is carried out civilized, full of respect and appreciation, not demeaning the interlocutor, avoiding debate, avoiding conflict and division, and so on (Ariani, 2012). The internet and social media are communication channels used to convey messages of goodness (da'wah). In this case, the communication channel must strengthen the relationship between Muslims (interaction) and strengthen social cohesiveness (integration). Communication media is used as a space for internalization, diffusion, actualization, a transformation of Islamic values (Suharto, 2013). Thus, da'wah communication is used as an approach to counter hoax narratives.

Some of the characteristics of messages or information in the Islamic review as a framework for strengthening da'wah communication to prevent hoaxes include. First, the information conveyed must display the actual story or news (naba al-haq). Namely, information that strengthens the heart of the recipient with the truth (Qs. 11: 120), information that does not hide the truth from the community (Qs. 49: 9), information that can resolve differences (Qs. 2: 213), information that does not lead to presumptions (Qs. 2: 213). Qs. 3: 154), and information that only follows subjective satisfaction (Qs. 5:48). Second, the information conveyed is oriented towards amar maruf nahi munkar (Qs. 3: 110). Third, the information conveyed contains firm and steadfast words (bikmah), goes through a clarification process (tabayyun), contains examples and examples (mavidzah hasanah), and uses soft and touching language (layyin) (Kahfi, 2006).

Da'wah communication is also carried out to exercise social control over disseminating information in the community, especially information with a negative tendency (Rohman, 2019). In this case, the information that needs to be controlled through da'wah communication is information that contains skhariyyah and talmizah (demeaning others), su'udzan and tubmab (containing elements of suspicion or presumption), tajaasas (trying to find fault with others), ghibah (gossiping about others), bubtan (subjective addition with the intention of slander), and ifleun (reverse facts) (Kahfi, 2006). These things form the framework for da'wah communication that is carried out to prevent the spread of hoax news, thereby significantly strengthening social cohesiveness and integration (Rustandi \& Muchtar, 2020). 


\section{Media Efforts of LDNU's in Preventing Hoax News}

In response to hoax news, the Nahdlatul Ulama Da'wah Institution (LDNU) has received support from various groups. Among them is the Vice President of the Republic of Indonesia, Prof. Dr. (H.C.). K.H. Ma'ruf Amin and the General Chairperson of the Nahdlatul Ulama Executive Board Prof. Dr. K.H. Said Aqil Siraj, M.A. Ma'ruf Amin expressed his support and appreciation for the LDNU movement in creating a program of 34,000 da'i on social media. Ma'aruf Amin considers the program to prevent and fight hoaxes (Ikhsanudin, 2019). Meanwhile, PBNU General Chair K.H. Said Aqil Siraj said warding off slander, hoaxes, and insults to innocent people is a religious duty. N.U. Residents who have qualified knowledge should not be silent. When conditions are good, they can be silent (tawadlu), but they must straighten it out when there is a hoax (Ulwan, 2020).

The prevention of hoax news by the NU Da'wah Institution is carried out actively through social media. This is done by disseminating news and information with nuances of advice to the public. For example, in preventing hoax news, the NU Da'wah Institute always urges the entire community to use social media to avoid division and hostility. Moreover, spreading hoax news is not behavior that does not show kindness. This effort is made to build perceptions in the community to be aware and critical when receiving information. The accompaniment process is carried out by touching the emotional dimension of the listener so that they can motivate and move. In a communication review, the application of persuasive communication will lead to people's emotions (Salam, 2018: 315). In addition, this is a part of positive public journalism that places the objectivity and truth of information obtained through the media objectively, where the principles of balance and openness are seen as strengthening public perceptions of information or news (Holding, 2012: 8).

Internally, LDNU also faces digital threats in countering hoax news. The threat relates to accusations addressed to LDNU as one of the institutions under the Islamic organization Nahdlatul Ulama. As can be seen in Figures 1 and 2 below: 
Picture. 1. da'wahnu.id

IEUBAGA DAKWAH

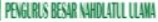

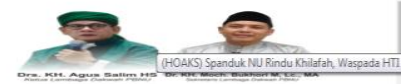

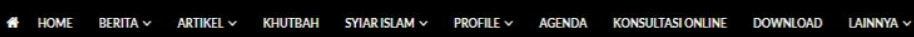

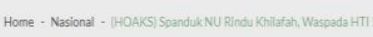

\section{mosoner}

(HOAKS) Spanduk NU Rindu Khilafah, Waspada HTI !

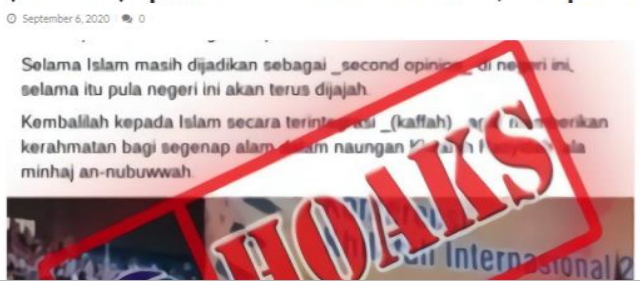

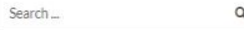

Trending Posts

Sugi Nur-Refly Harun, Bukti' 'Suul Adab Paling Konkret! GP Ansor Slap Tindak

Tegas

October 20,2020

Ramai Polemik UU Ciptaker, Wapres aran ke PBNU

October 17,2020

Jakowi Utus Mensesneg Serahkan Draf UU Ciptaker ke PBNU October 19.2020

Source: LDNU official media

Figure 1 was published by da'wahnu.id regarding the traces of the caliphate by unfurling a banner that reads "Nahdliyah Citizens Longing for the Khilafah" in 2003, long before KH. Said Aqil Siraj became the leader of PBNU. However, after the image was tracked and checked by trunbackhoax.id in 2019, it was explained that it was taken in August 2007. HTI indeed organized the event. Ismail Yusanto said that he also invited KH. Zainuddin MZ, Amin Rais, and participants from abroad. Another opinion, H. Helmy Faizal Zaini, as the Secretary-General of PBNU, in his confirmation, emphasized that the banner was only for profiting $\mathrm{NU}$ residents, not officially issued by NU. From these facts, the claim that the banner that reads "Nahdliyah Citizens Longing for the Khilafah" is wrong because it is not official and is not an NU output. 
Picture. 2. dakwahnu.id

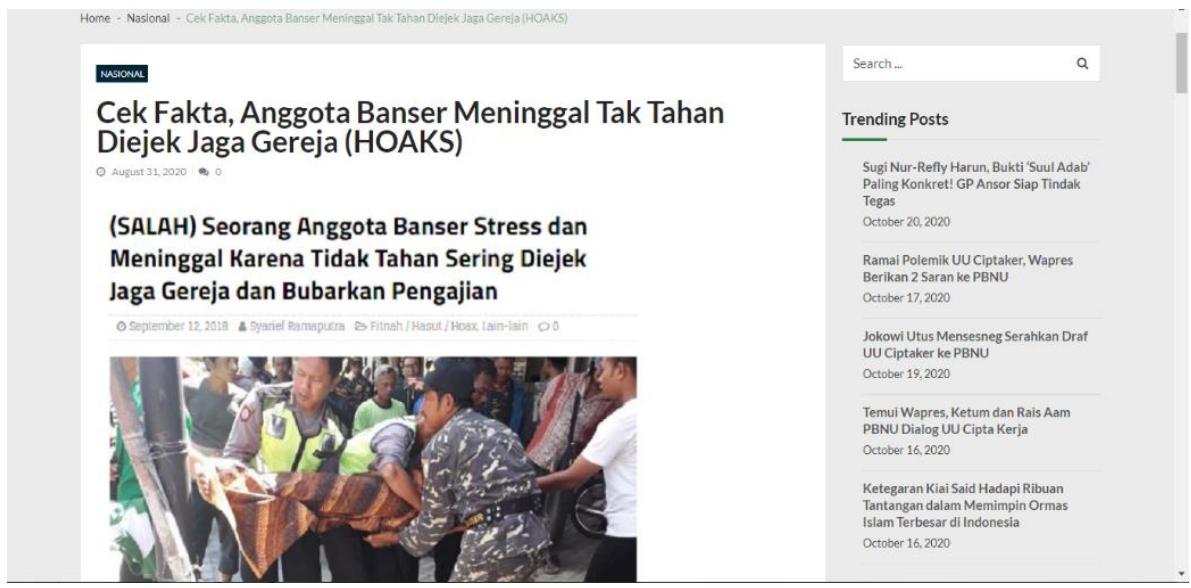

Source: LDNU official media

Figure 2 shows the title "A Banser Member is Stressed and Dies Because He Cannot Stand Being Riddened, Guard the Church and Disband the Study." This narrative is circulating on social media on Alang Saputra's account (fb.com/dadang.akhmadsadly). This news was published on 7 September 2018 at 16.23 WIB. Based on the fact checks from turnbackhoax.id. he stated that old photos are being used again to create hoaxes. The factual information is that a banser member died in an accident, not what was stated in the news title.

Freedom of information must be chosen wisely and adequately and does not violate the norms of social life (Hana, 2019: 1). From the two examples above, the NU Da'wah Institute strives for the prevention of hoaxes to be carried out through digital media, especially social media. LDNU has various kinds of social media in its efforts, such as Instagram @1dnu1926, Twitter@ldnu1926, PBNU Da'wah Institution facebook, and the old da'wahnu.id website. In this effort, the wisdom of social media users is essential in the anti-hoax da'wah communication process because hoaxes have a significant impact in destroying the basis of communication and norms of social life.

Practically and implement a timely, the NU Da'wah Institute's communication efforts in preventing hoaxes include the following: First, LDNU creates social media accounts for Instagram, Facebook, Twitter, and websites to protect messages conveyed by various media if there are indications of hoaxes. The communicator's message to the communicant 
must be appropriate, and there is no defect in the news, let alone fake news. Second, LDNU collaborates with TVRI and the website turnbackhoax.id, managed by MAFINDO, to narrow the space for slander and hoaxes. Third, LDNU continues to use the basis of the ITE Law as a guide in the use of social media. These three efforts are consistently and continuously to build a public perception to prevent hoax news. In other words, LDNU carries out its prevention role through education, outreach, and positive information campaigns as a counter to false information.

Regarding the level of digital literacy, LDNU has become an important focus. In this case, LDNU is guided by the ITE Law, digital literacy, and religious guidelines regarding social media muamalah. This is done to build public awareness of NU regarding filtering information that is a hoax and hate speech. Therefore, LDNU emphasizes several principles of using social media as a guide for interacting. So that the condition of a wise and critical society is built in responding to issues that develop in the digital space, some of these principles include:

First, the Principle of Honesty. LDNU does this by implementing a journalistic code of ethics in the production process and disseminating messages to the public, both related to internal and external interests. Second, the Principle of Cleanliness. This is done by producing positive, argumentative, and socially responsible content. In addition, LDNU avoids provocative, manipulative messages and can potentially disintegrate the nation.

Third, the Principle of Positive Saying. This is done by instilling Islamic communication ethics in journalists and LDNU official media managers. This is an effort to strengthen the strategic role of LDNU. Fourth, the Supervision Principle. This is done by involving Nahdliyin residents in the information management process, including applying the principle of citizen journalism as part of social control over information circulating in an active and participatory manner.

Fifth, Selectivity and Validity Principles. It is carried out with the tabayyun process or verification of the news submitted. In addition, LDNU seeks to build collaborations with the media and other communities concerned about preventing the dissemination of hoaxes. Sixth, the Principle of Mutual Influence. This is done by strengthening the base of awareness, knowledge, and skills in responding to hoax news or information.

Seventh, the Principle of News Balance. This is done by applying a 
journalistic code of ethics in producing, selecting, and distributing communication messages. LDNU intensively provides journalists and media managers a briefing on increasing knowledge and capacity. Eighth, Personality Principle. This is done by maintaining the institution's good name and everyone involved in the management of LDNU. This includes public involvement in the message dissemination process.

\section{CONCLUSION}

The efforts made by LDNU in building public perception to prevent hoax news through mass media are based on concerns and concerns about the flood of information that occurs in cyberspace. This effort is carried out on an institutional basis by carrying out a da'wah communication process oriented towards truth and goodness. LDNU, as an institution under the Nahdlatul Ulama Community Organization, carries out preventive efforts actively and collaboratively in increasing public awareness and awareness of hoax news. This is done by paying attention to ethics and communication principles oriented towards Islamic da'wah activities.

Practically and practically, the efforts made by LDNU in preventing hoax news through mass media include: first, LDNU creates social media accounts for Instagram, Facebook, Twitter, and websites to maintain and ensure messages conveyed by various media that are indicated as hoaxes. The communicator's message to the communicant must be appropriate, and there are no defects in the news, especially fake news; second, LDNU cooperates with TVRI, and the website turnbackhoax.id which MAFINDO manages to narrow the space for slander and hoaxes; and third, LDNU continues to use the basis of the ITE Law as a guide in the use of social media.

In addition, several principles of using social media that LDNU applies to prevent hoaxes: honesty, cleanliness, positive speech, supervision, selectivity and validity, mutual influence, news balance, and personality. These eight principles are an integral part of building awareness, perception, knowledge, skills, and social responsibility in preventing the spread of hoax news and other harmful content.

\section{REFERENCES}

Ali, M. (2017). Antara Komunikasi, Budaya dan Hoax, Melawana Hoax di Media Sosial Dan Media Massa. Yogyakarta: ASKOPIS PRESS. 
Alif, M. Ismail.T, Yudo, dkk. (2018). Media Dalam Menanggulangi Berita Hoax (Studi Pada Pelajar SMKN 4 Bekasi dan Mahasiswa AKOM BSI, Jakarta), Jurnal: Abdimas BSI,1(3), 416-423. DOI: https://doi.org/10.31294/jabdimas.v1i3.4052.

Ariani, A. (2012). Etika Komunikasi Dakwah menurut Al-Quran, Alhadharah, 11(21), 7-16. DOI: http://dx.doi.org/10.18592/alhadharah.v11i21.1782.

Asosiasi Penyelenggara Jasa Internet Indonesia (APJII), Hasil Survei Penetrasi Pengguna Internet di Indonesia, 2019-2020, diakses 20 Desember 2021, https://apjii.or.id/survei.

Bosma, F. D., \& Firdaus, M. (2017). Fenomena Komunikasi Komunitas kelas Inspirasi (Studi Fenomenologi Social Movement Pada Anggota Komunitas kelas Inspirasi Pekanbaru, Jurnal Online Mahasiswa FISIP, 4(2),

https://jom.unri.ac.id/index.php/JOMFSIP/article/view/15574.

Buente, W. A., \& Robbin. (2008). Trends in Internet Information Behavior: 20002004.

Fakhruroji, M., Rustandi, R., \& Busro. (2020). Bahasa Agama di Media Sosial: Analisis Framing pada Media Sosial Islam Populer, Jurnal Bimas Islam, 13(2), 203-234. https:/ / doi.org/10.37302/jbi.v13i2.294.

Floridi, L. (2010). The Cambridge Handbook of Information and Computer Ethics. Cambridge: Cambridge University Press.

Hana, N., Januanti, A. R., dkk. (2019). Komunikasi dan Media Sosial, Jurnal Researchgate.

Harley, D. (2008). Common Hoaxes and Chain Letters. San Diego: ESET, LLC. Holding, M. (2012). Jurnalisme Positif. Jakarta: Berita Satu.

Ikhsanudin, A. (2019). Ma'ruf Amin Minta Dai Medsos LDNU Tangkal Hoax dan Radikalisme, diakses pada 20 Desember 2021, https://news.detik.com/berita/d-4404347/maruf-amin-minta-daimedsos-ldnu-tangkal-hoax-dan-radikalisme.

Ilahi, H. N. (2018). Woman and Hoax News Processing on WhatApp, Jurnal Ilmu Sosial dan Ilmu Politik, 22(2).

Istriyani, R., \& Widiana, N. H. (2016). Etika Komunikasi Islam dalam Membendung Informasi Hoax di Ranah Publik Maya, Jurnal Ilmu Dakwah, 36(2), 288-315. DOI : 10.21580/jid.v36.2.1774.

Juditha, C. (2018). Interaksi Komunikasi Hoaks di Media Sosial serta Antisipasinya, Jumal Pekommas, 3(1), 31-44. DOI: http://dx.doi.org/10.30818/jpkm.2018.2030104. 
Juliswara, V. (2017). Mengembangkan Model Literasi Media yang Berkebhinnekaan dalam Menganalisis Informasi Berita Palsu (Hoaks) di Media Sosial, Jurnal Pemikiran Sosiologi, 4(2), 142-164. https://doi.org/10.22146/jps.v4i2.28586.

Kahfi, A. S. (2006). Informasi dalam Perspektif Islam, MediaTor, 7(2), 321328.

https://ejournal.unisba.ac.id/index.php/mediator/article/viewFile /1274/830.

Kamarudin. (2015). Komunkasi Politik, Univeristas Malikus Shaleh.

Kementerian Komunikasi dan Informatika, Dirjen APTIKA, (2020). https://aptika.kominfo.go.id/2020/05/kominfo, diakses pada tanggal 12 Oktober 2020, Pukul 16:56

Kusnawan, A., \& Rustandi, R. (2021). Menemukan Moderasi Beragama dalam Kaderisasi Dakwah: Kajian pada Pemuda Persatuan Islam Jawa Barat, Nalar: Jurnal Pemikiran dan Peradaban Islam, 5(1), 41-61. DOI: https://doi.org/10.23971/njppi.v5i1.2900.

Lazonder, A. W., Biemans, H. J. A, \& Wopereis, I. G. J. H. (2000) Differences between novice and experienced users in search information on the World Wide Web. https://doi.org/10.1002/(sici)1097-4571(2000)51:6<576::aidasi9>3.0.co.

Manalu, S. R., Padekso, T., \& Setyabudi, D. (2018). Understanding the Tendency of Media Users to Consume Fake News, Jurnal Ilmu Komunikasi, 15(1), $1-16$.

DOI: https://doi.org/10.24002/jik.v15i1.1322.

Mulyana, D. (2010). Ilmu Komunikasi Suatu Pengantar, Cet. XIV. Bandung: PT. Remaja Rosdakarya.

Respati, S. (2017). Mengapa Banyak Orang Mudah Percaya Berita "Hoax"?, diakses pada 25 November 2021, Kompas.com. Retrieved from http:// nasional.kompas.com/read/2017/0

1/23/18181951/mengapa.banyak.orang. mudah.percaya.berita.hoax.

Ridwan, A. (2016). Komunikasi Antarbudaya (mengubah Persepsi dan Sikap dalam Meningkatkan Kreativitas Manusia). Bandung: Pustaka Setia.

Ridwan, A., Dulwahab, E., Rustandi, R., \& Fatoni, U. (2021). Dakwah Sejuk dan Peran Lembaga Penyiaran dalam Mencegah Radikalisme. Laporan Penelitian Kerjasama KPID Jawa Barat dan Fakultas Dakwah dan Komunikasi UIN Sunan Gunung Djati Bandung. 
Mustafirin \& Hatta Abdul Malik

Rohman, D. A. (2019). Komunikasi Dakwah melalui Media Sosial, Tatar Sunda, 13(2),

121-133.

DOI: https://doi.org/10.38075/tp.v13i2.19.

Rustandi, R. (2019). Cyberdakwah: Internet Sebagai Media Baru Dalam Sistem Komunikasi Dakwah Islam, Nalar: Jurnal Pemikiran dan Peradaban Islam, 3(2), 84-95. DOI : 10.23971/njppi.v3i2.1678.

Rustandi, R. (2020). Dakwah Komunitas di Pedesaan dalam Perspektif Psikologi Komunikasi, Irsyad: Jurnal Bimbingan, Penyuluban, Konseling, dan Psikoterapi Islam, 8(3), 301-322. DOI 10.15575/irsyad.v8i3.200.

Rustandi, R., \& Hanifah, H. (2019). Dinamika Dakwah Komunitas Remaja Islam di Kecamatan Pangalengan, ANID A (Aktualisasi Nuansa Imu Dakwab), 19(2), 199-224. DOI :10.15575/anida.v19i2.7540.

Rustandi, R., \& Muchtar, K. (2020). Analisis Framing Kontra Narasi Terorisme dan Radikalisme di Media Sosial (Studi Kasus pada Akun (a)dutadamaijabar), Komunikatif: Jurnal Ilmiah Komunikasi, 9(2), 134152.

DOI: https://doi.org/10.33508/jk.v9i2.2698.

Rustandi, R., \& Sahidin, S. (2019). Analisis Historis Manajemen Dakwah Rosulullah Saw dalam Piagam Madinah, Tamaddun: Jurnal Sejarah dan Kebudayaan Islam, 7(2), 362-387. DOI: 10.24235/tamaddun.v7i2.5503.g2562.

Salam, A. (2018). The Hoax Phenomenon in Indonesia Society: Observing Anti-Diversity Memes since 2014, Journal of Humaniora, 30(3), 315324. https://doi.org/10.22146/jh.38891.

Septanto, H. (2018). Pengaruh Hoaks dan Ujaran Kebencian Sebuah Cyber Crime Dengan Teknologi Sederhana di Kehidupan Sosial Masyarakat, Kalbis Scientia: Jurnal Sains dan Teknologi, 5(2), 157-162.

Silalahi, R. R., Bestari, P., \& Saputra, W. T. (2017). Karakteristik Stategi Crowdsourcing untuk Membatasi Penyebaran Hoaks di Indonesia, Metacommunication: Journal of Communication Studies, 2(2), 128-154. DOI: http://dx.doi.org/10.20527/mc.v2i2.4090.

Siswoko, K. H. (2017). Kebijakan Pemerintah Menangkal Penyebaran Berita Palsu atau Hoaks, Jurnal Muara Ilmu Sosial, Humaniora, dan Seni, 1(1), 13-19. DOI: 10.24912/jmishumsen.v1i1.330.

Suharto. (2013). Komunikasi Dakwah: Interaksi dan Integrasi Media Sosial, Al-Mishbah, $9(1)$ 89-100.

https://almishbahjurnal.com/index.php/almishbah/article/view/22. 
Sukmana, O. (2013). Konvergensi Antara Resource Mobilization Theory dan Idendity Oriented Theory Dalam Studi Gerakan Sosial, Jurnal Sosiologi Reflektif, 8(1), 41-62. http://ejournal.uinsuka.ac.id/isoshum/sosiologireflektif/article/view/524.

Tarigan, A. (2017). Menko Polbukam: berita "boax" buat masyarakat merugi, diakses pada $20 \quad$ Desember 2021, http://www.antaranews.com/berita/604730/menkopolhukamberita-hoax-buat-masyarakat-merugi).

Ulwan, A. F. (2020). Warga dan Santri NU Jangan Diam, Harus Kuasai Media Massa, diakses pada 20 Desember 2021, https:/ / dakwahnu.id/wargadan-santri-nu-jangan-diam-harus-kuasai-media-massa/.

Utami, P. (2018). Hoax in Modern Politics: The Meaning of Hoax in Indonesian Politics and Democracy, Jurnal Ilmu Sosial Dan Ilmu Politik, 22 (2), 85-97. https://doi.org/10.22146/jsp.34614.

We Are Social. "We Are Social, Digital Around the World in 2021." Diakses pada 20 Desember 2021, https://wearesocial.com/uk/blog/2021/01/digital-2021-the-latestinsights-into-the-state-of-digital/.

Ya'qub, H. (1998). Etika Islam. Bandung: Diponegoro. 
